\title{
Interventions to improve the well-being of medical learners in Canada: a scoping review
}

\author{
Stephana J. Moss MSc, Krista Wollny RN MN, Mungunzul Amarbayan MPP, Diane L. Lorenzetti PhD, \\ Aliya Kassam $\mathrm{PhD}$
}

Abstract

Background: Medical education affects learner well-being. We explored the breadth and depth of interventions to improve the wellbeing of medical learners in Canada.

Methods: We searched MEDLINE, EMBASE, CINAHL and PsycINFO from inception to July 11, 2020, using the Arksey-O'Malley, 5-stage, scoping review method. We included interventions to improve well-being across 5 wellness domains (i.e., social, mental, physical, intellectual, occupational) for medical learners in Canada, grouped as undergraduate or graduate nonmedical (i.e., health sciences) students, undergraduate medical students or postgraduate medical students (i.e., residents). We categorized interventions as targeting the individual (learner), program (i.e., in which learners are enrolled) or system (i.e., higher education or health care) levels.

Results: Of 1753 studies identified, we included 65 interventions that aimed to improve well-being in 10202 medical learners, published from 1972 through 2020; 52 (80\%) were uncontrolled trials. The median year for intervention implementation was 2010 (range 1971-2018) and the median length was 3 months (range $1 \mathrm{~h}-48 \mathrm{mo})$. Most $(n=34,52 \%)$ interventions were implemented with undergraduate medical students. Two interventions included only undergraduate, nonmedical students; none included graduate nonmedical students. Most studies $(n=51,78 \%)$ targeted intellectual well-being, followed by occupational $(n=32$, 49\%) and social ( $n=17,26 \%$ ) well-being. Among 19 interventions implemented for individuals, 14 (74\%) were for medical students; of the 27 programlevel interventions, 17 (63\%) were for resident physicians. Most $(n=58,89 \%)$ interventions reported positive well-being outcomes.

Interpretation: Many Canadian medical schools address intellectual, occupational and social well-being by targeting interventions at medical learners. Important emphasis on the mental and physical well-being of medical learners in Canada warrants further exploration.

oncerns exist about the impact of medical education on learner well-being. ${ }^{1-4}$ Programs housed within medical schools often address intellectual and occupational well-being, focusing specifically on skills related to learning and working; $;^{5,6}$ however, well-being is a multidimensional construct. Social, mental, and physical wellbeing have been shown to be negatively affected during undergraduate medical education, ${ }^{7}$ with increased prevalence of burnout in residency. ${ }^{8,9}$ Poor well-being can affect medical learners across the spectrum of programs, including undergraduate health sciences. ${ }^{10}$

The Canadian Federation of Medical Students aims to "train healthier physicians to maximize the productivity and quality of health care services for Canadians." gic directions for 2020-2022 include developing health promoting communities, promoting a positive culture in medical education that prioritizes learner well-being, increasing collaboration within the medical community and optimizing student resources. Despite the growing literature as universities implement services to address the well-being of medical learners, earlier reviews on this topic have not evaluated interventions in Canadian medical schools and have found it difficult to define medical learner well-being. ${ }^{12,13}$

The Wellness Innovation Scholarship for Health Professions Education and Health Sciences (WISHES) laboratory at the University of Calgary is taking a holistic approach to medical learner well-being. ${ }^{14}$ Based on Nussbaum's human capabilities approach ${ }^{15}$ and acknowledging that well-being is multidimensional, ${ }^{16}$ WISHES focuses on measurable outcomes within the domains of mental, physical, occupational,

Competing interests: None declared.

This article has been peer reviewed.

Correspondence to: Stephana Moss, stephana.moss@ucalgary.ca

CMAJ Open 2021. DOI:10.9778/cmajo.20200236 
social, and intellectual well-being for individual learners and teachers, health professions education and training programs, and the intersection of the higher education system and the health care system. ${ }^{17}$

We conducted a scoping review that builds on previous literature and uses the WISHES holistic approach to well-being to explore the breadth and depth of interventions that aim to ultimately improve well-being among medical learners in Canada.

\section{Methods}

\section{Study design}

Based on Joanna Briggs Institute's Review Manual ${ }^{18}$ and the Arksey-O'Malley methodological framework, ${ }^{19}$ we used 5 steps for our review: identifying the research question, identifying relevant studies, study selection, charting the data, and collating, summarizing and reporting results.

\section{Identifying the research question}

Our primary research question was "What is the breadth and depth of interventions aimed to improve well-being among Canadian medical learners?" We included any intervention that aimed to improve well-being of medical learners in Canada, with any comparator or outcome.

\section{Identifying relevant studies}

We searched MEDLINE, EMBASE, CINAHL and PsycINFO from inception to July 11, 2020. We developed search strategies with an experienced medical librarian (D.L.L.), which combined synonyms and subject headings from 3 concepts: medical learners in Canada, well-being and interventions. We also searched review databases to identify review articles to screen reference lists for studies missed in our initial search. One author (S.J.M.) conducted all searches and reviewed reference lists. The complete MEDLINE search strategy is provided in Appendix 1, Supplemental Table 1, available at www.cmajopen. ca/content/9/3/E765/suppl/DC1.

Our inclusion criteria were that studies from any publication year be primary research of interventions (e.g., mentoring, or educational interventions) for medical learners in Canada that aimed to improve well-being. We excluded studies if they were not primary research (e.g., editorials) or did not report any outcome from an intervention aimed to improve well-being. We defined a medical learner as an individual registered in an academic institution whose program is housed in a Canadian medical school and pertains to research or treatment of diseases and injuries or relating to medicine (i.e., undergraduate medical student, postgraduate medical student [resident physician], undergraduate nonmedical [health sciences] student, graduate science $[\mathrm{MSc}$ or $\mathrm{PhD}]$ student). ${ }^{20}$ We defined an intervention as any randomized or nonrandomized experimental study. We included studies if wellbeing was 1 component of a multicomponent intervention (e.g., education intervention to address intellectual well-being, not just clinical skills). We selected domains of well-being (i.e., social, mental, physical, intellectual, occupational) ${ }^{14}$ for our scoping review based on a needs assessment performed among medical learners at a Canadian medical institution; we validated operational definitions for domains. ${ }^{21}$

We used broad inclusion criteria (inclusive of all medical learners) to explore the breadth and depth of well-being support among medical learners as they transition through their studies into a health care profession. Understanding the comprehensiveness of well-being support throughout the academic trajectory will benefit efforts to develop effective interventions for students as they transition through medical education. ${ }^{22}$

\section{Study selection}

Three authors (S.J.M., K.W., M.A.) reviewed titles and abstracts, independently and in duplicate, after achieving $100 \%$ agreement on a pilot test of 50 random studies. The same authors reviewed the full text of selected articles, independently and in duplicate; we included articles in the final review if both reviewers agreed on inclusion. A fourth author (A.K.) resolved disagreements.

\section{Charting the data}

Independently and in duplicate, we (S.J.M., K.W., M.A., A.K.) charted data for included studies using a data collection sheet that was developed and piloted by the review team, resolving discrepancies through discussion. We collected information on document characteristics (e.g., year, geographic location), study characteristics (e.g., medical school, time frame), learner group, intervention domains (i.e., social, mental, physical, intellectual, occupational), level of intervention (i.e., individual, program, system), outcomes (e.g., assessment measures, themes or theories), limitations and conclusions.

\section{Data analysis}

We synthesized findings descriptively (Table 1) and categorized the level of intervention as targeted to the individual (i.e., the individual learner or group of individual learners), program (i.e., the program in which the learner is enrolled) or system (i.e., the academic institution or health care system in which learners learn or work). We recorded the primary level for each intervention. We categorized outcomes within 5 validated domains of well-being ${ }^{21}$ that represent part of the multidimensional construct of well-being: social (e.g., equity, diversity), mental (e.g., mindfulness, emotions), physical (e.g., exercise, nutrition), intellectual (e.g., tools, education) and occupational (e.g., research, resident rotation). Multiple outcomes (within multiple domains) could be recorded for each intervention.

We (S.J.M., K.W., M.A., A.K.) synthesized results from included qualitative studies using thematic synthesis for reviews on health research. ${ }^{23,24} \mathrm{We}$ developed discrete themes that represented findings reported in primary studies, and considered these themes to generate new interpretive constructs, explanations or hypotheses. ${ }^{25} \mathrm{We}$ integrated our qualitative and quantitative findings by using qualitative results to interrogate quantitative results, to identify research gaps and to synthesize lines of inquiry. ${ }^{26}$ 


\begin{tabular}{|c|c|c|}
\hline $\begin{array}{l}\text { Well-being } \\
\text { domain }\end{array}$ & Description & Examples \\
\hline Social & $\begin{array}{l}\text { State of well-being in which individuals and communities feel } \\
\text { they understand, are a part of, and are accepted by their social } \\
\text { environment, and are comfortable expressing their feelings, } \\
\text { needs, identities and opinions. }{ }^{16} \text { This includes processes } \\
\text { (methods) and outcomes (experiences) of social well-being. }\end{array}$ & $\begin{array}{l}\text { Isolation, imposterism, equity, diversity, } \\
\text { discrimination, race, religion, ethnicity, family support }\end{array}$ \\
\hline Mental & $\begin{array}{l}\text { State of well-being in which every individual realizes his or her } \\
\text { own potential, can cope with the normal stresses of life, can work } \\
\text { productively and fruitfully, and is able to make a contribution to } \\
\text { her or his community. }\end{array}$ & $\begin{array}{l}\text { Mindfulness, mental health, mental illness or } \\
\text { disorder, anger, sadness, emotions }\end{array}$ \\
\hline Physical & $\begin{array}{l}\text { Perception and expectation of well-being of an individual's body, } \\
\text { including the active and continuous effort to maintain optimum } \\
\text { levels of physical activity and focus on nutrition, as well as } \\
\text { self-care and maintenance of a healthy lifestyle. }{ }^{16} \text { This } \\
\text { acknowledges physical health and limitations can coexist in a } \\
\text { healthy environment. }\end{array}$ & $\begin{array}{l}\text { Exercise, physical activity, physical health, nutrition, } \\
\text { symptoms of burnout }\end{array}$ \\
\hline Intellectual & $\begin{array}{l}\text { State of well-being in which individuals are enabled to pursue } \\
\text { creative, mentally stimulating activities that expand their } \\
\text { knowledge, develop skills, and foster life-long learning and } \\
\text { teaching, toward a goal of self-actualization. }{ }^{16} \text { This includes } \\
\text { processes (how) and outcomes (deliverables) of intellectual } \\
\text { well-being. }\end{array}$ & $\begin{array}{l}\text { Learning, tools, outcomes, teaching, goals, learning } \\
\text { needs }\end{array}$ \\
\hline Occupational & $\begin{array}{l}\text { Protection and promotion of workers or learners by preventing } \\
\text { and controlling occupational diseases and accidents, and by } \\
\text { elimination of conditions hazardous to health and safety at work } \\
\text { or school, and the development and promotion of healthy and } \\
\text { safe work or learning, work or learning environments and } \\
\text { organizations. }{ }^{24} \text { This includes processes (responsibilities) and } \\
\text { outcomes (trajectories) of occupational well-being. }\end{array}$ & $\begin{array}{l}\text { Work, (resident) rotation, job, laboratory, research } \\
\text { (assistantship or similar) }\end{array}$ \\
\hline
\end{tabular}

We classified reported outcomes for each well-being domain as statistically significant if $p<0.05$. We calculated descriptive statistics using STATA IC15 (StataCorp).

\section{Ethics approval}

We did not require ethics approval as all data were available in published records.

\section{Results}

Of 1753 relevant studies identified, we included 65 interventions that aimed to improved medical learner well-being (Figure 1). Characteristics of included studies are in Appendix 2, Supplemental Table 2, available at www.cmajopen.ca/ content/9/3/E765/supp1/DC1.27-91

The 65 included studies ${ }^{27-91}$ were published between 1973 and 2020, and were conducted most frequently at University of Toronto $(n=16,25 \%)$ or McGill University $(n=8,12 \%)$ with undergraduate $(n=34,52 \%)$ or postgraduate medical education students $(n=31,48 \%)$ (Figure 2). Figure 3 illustrates the cumulative number of published studies on interventions. Among 44 studies that reported implementation year, the median was 2010 (range 1971-2018). The median intervention duration, reported from 47 studies, was 3 months (range $1 \mathrm{~h}-48 \mathrm{mo}$ ). Most studies $(n=52,80 \%)$ were uncontrolled trials, of which half were implemented with undergraduate medical students $(n=26)$. We included 16 qualitative studies; most $(n=9)$ were conducted with undergraduate medical students. Resident physicians were commonly from family medicine $(n=6)$ and pediatrics $(n=6)$, which included pediatric subspecialties $(n=2)$; generalist practice was more broadly defined $(n=4)$.

Fifty-one $(78 \%)$ interventions targeted intellectual (e.g., clinical skills modules ${ }^{46}$ ) well-being and $32(49 \%)$ targeted occupational well-being (e.g., resident rotation bun$\left.\mathrm{dle}^{47}\right) ; 23$ (35\%) targeted both domains (e.g., specialty exploration and discovery programs ${ }^{92}$ ). Among 19 interventions for individuals, most $(n=14)$ were for medical students. Program interventions $(n=27)$ were primarily for resident physicians $(n=17)$. Medical students and residents were represented similarly in system interventions (undergraduate, $n=9$; postgraduate, $n=10$ ). Two system interventions were for undergraduate health sciences students. Few studies $(n=2)$ incorporated formal mentorship programs in their intervention as a method to promote learner well-being. Only 3 studies considered barriers or stigma among medical learners to accessing appropriate mental health services.

\section{Quantitative studies}

Quantitative outcomes are reported in Appendix 3, Supplemental Table 3, available at www.cmajopen.ca/content/9/3/ 


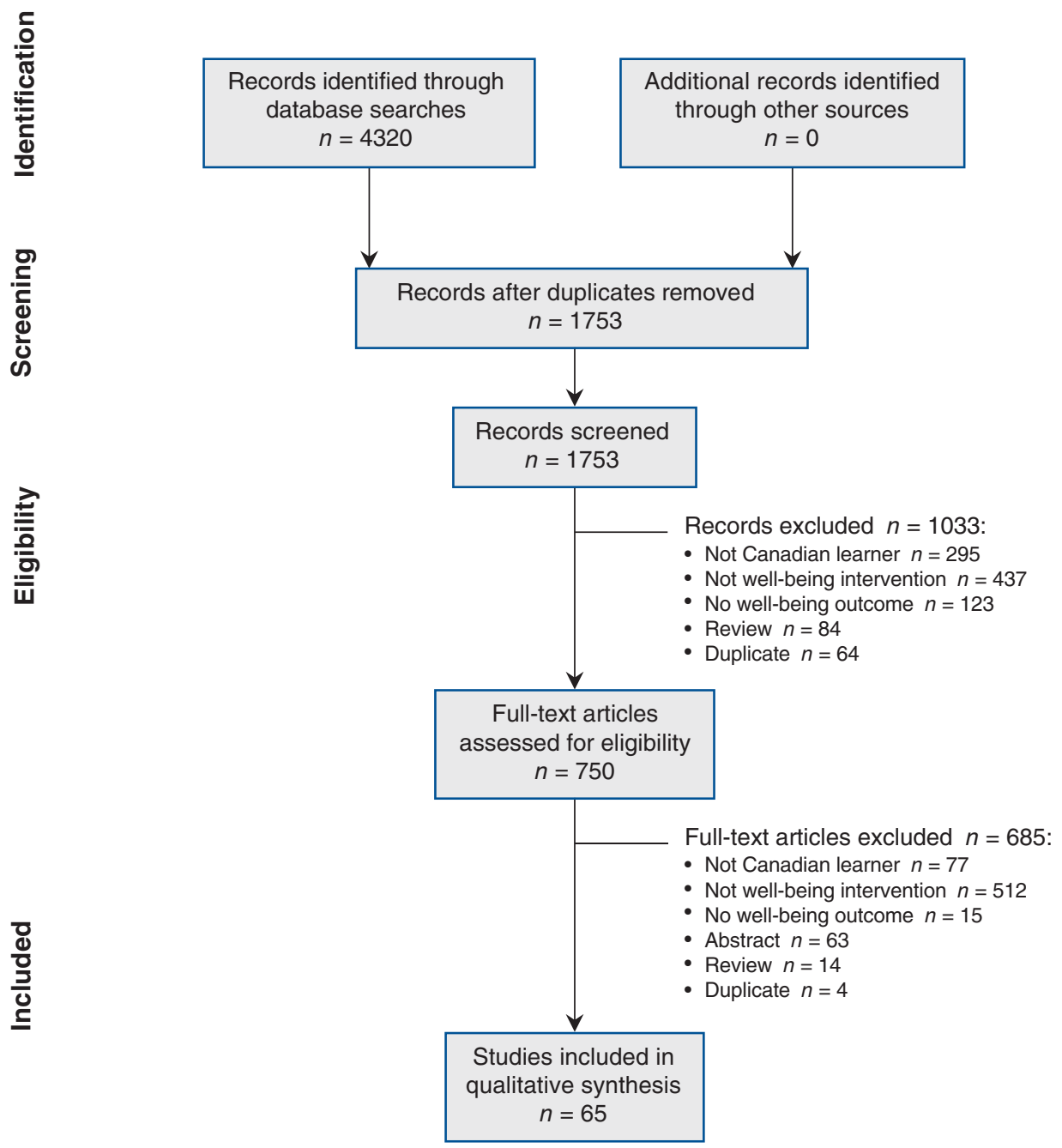

Figure 1: Study flow diagram.

E765/suppl/DC1. Statistical evaluation of interventions was explored extensively $(n=41,63 \%)$, namely evaluating perceptions of well-being pre- and postintervention, satisfaction with the intervention, and determining attitudes and agreement regarding use of interventions. Figure 4 illustrates the number of studies that reported a significantly positive effect of interventions by well-being domain, level of intervention and learner group. In Appendix 4, available at www.cmajopen.ca/content/9/3/E765/suppl/DC1, we provide summaries on assessment tools used to measure outcomes within well-being domains, as well as a summary of statistical findings.

\section{Qualitative studies}

Sixteen studies explored well-being qualitatively. Most $(n=12)$ focused on promoting and understanding intellectual well-being in medical education (Table 2). Five qualitative studies reported favourable outcomes; 3 studies concluded that formal audit is needed ${ }^{34,79,77}$ and 2 studies uncovered shortcomings related to postgraduate education content (i.e., intellectual, occupational well-being) ${ }^{84}$ and undergraduate medical education leadership (i.e., social, intellectual well-being). ${ }^{33}$

A key finding was that well-being among learners is a multidimensional construct that includes 4 components: genuine sense of personal fulfillment and gratification in medical education, grounded understanding of requirements for medical education programs, enhanced peer cohesion and functionality, and promoting cognitive flexibility to strengthen knowledge for diverse perspectives. Three conditions were identified as predicting and promoting well-being: effective coping and emotional regulation through individual strategies, individual 
Table 2 (part 1 of 2): Summary of findings from qualitative studies ${ }^{1,2 *}$

\begin{tabular}{|c|c|c|c|c|c|c|c|}
\hline Study & $\begin{array}{l}\text { Well-being } \\
\text { domaint }\end{array}$ & Level & $\begin{array}{l}\text { No. and type } \\
\text { of students }\end{array}$ & Intervention & Analysis & Themes or theory & $\begin{array}{l}\text { Author findings from } \\
\text { original study }\end{array}$ \\
\hline \multicolumn{8}{|c|}{ Undergraduate medical students } \\
\hline $\begin{array}{l}\text { Brown } \\
\text { et al., } \\
2018^{30}\end{array}$ & $\begin{array}{l}\text { Intellectual, } \\
\text { occupational }\end{array}$ & Individual & $\begin{array}{l}\text { 123; first-year } \\
\text { undergraduate } \\
\text { medical } \\
\text { students }\end{array}$ & $\begin{array}{l}\text { Program for } \\
\text { Improvement in } \\
\text { Medical Education } \\
\text { for engagement in } \\
\text { quality improvement } \\
\text { training }\end{array}$ & Thematic & $\begin{array}{l}\text { Continuous support; } \\
\text { genuine interest in } \\
\text { improving medical } \\
\text { education; team-based } \\
\text { learning and problem } \\
\text { solving; regular project } \\
\text { feedback; access to } \\
\text { education resources for } \\
\text { quality improvement }\end{array}$ & $\begin{array}{l}\text { Medical education is an } \\
\text { appropriate setting to } \\
\text { teach preclerkship } \\
\text { medical students about } \\
\text { quality improvement, } \\
\text { which might lead to } \\
\text { increased knowledge of } \\
\text { quality improvement. }\end{array}$ \\
\hline $\begin{array}{l}\text { Byszewski } \\
\text { et al., } \\
2017^{32}\end{array}$ & $\begin{array}{l}\text { Intellectual, } \\
\text { occupational }\end{array}$ & Individual & $\begin{array}{l}93 ; \\
\text { undergraduate } \\
\text { medical } \\
\text { students }\end{array}$ & $\begin{array}{l}\text { Multimedia podcast } \\
\text { resource on what a } \\
\text { geriatric specialty } \\
\text { entails }\end{array}$ & Thematic & $\begin{array}{l}\text { Students found the } \\
\text { podcast a creative method } \\
\text { to present a specialty and } \\
\text { suggested creating } \\
\text { podcasts for other medical } \\
\text { fields; students provided } \\
\text { suggestions for including } \\
\text { patient testimonials and "A } \\
\text { day in the life of ..." }\end{array}$ & $\begin{array}{l}\text { A multimedia podcast for } \\
\text { medical students can } \\
\text { raise awareness of } \\
\text { geriatric medicine as a } \\
\text { potential career choice } \\
\text { and can be used as a } \\
\text { novel multimedia } \\
\text { approach for a variety of } \\
\text { career options when } \\
\text { considering residency } \\
\text { programs. }\end{array}$ \\
\hline $\begin{array}{l}\text { Cadieux } \\
\text { et al., } \\
2017^{33}\end{array}$ & $\begin{array}{l}\text { Intellectual, } \\
\text { occupational }\end{array}$ & System & $\begin{array}{l}62 \text {; first-year } \\
\text { undergraduate } \\
\text { medical } \\
\text { students }\end{array}$ & $\begin{array}{l}\text { Leadership course } \\
\text { grounded in } \\
\text { business pedagogy }\end{array}$ & Thematic & $\begin{array}{l}\text { Understanding change; } \\
\text { effective teamwork; } \\
\text { leading in patient safety; } \\
\text { leadership in action }\end{array}$ & $\begin{array}{l}\text { Leadership in medical } \\
\text { education should be } \\
\text { applicable to the learner's } \\
\text { stage of training and may } \\
\text { be better supported if } \\
\text { leadership is framed as a } \\
\text { competency throughout } \\
\text { their career. }\end{array}$ \\
\hline $\begin{array}{l}\text { Chew et al., } \\
2012^{36}\end{array}$ & $\begin{array}{l}\text { Intellectual, } \\
\text { occupational }\end{array}$ & Individual & $\begin{array}{l}\text { 18; second-year } \\
\text { undergraduate } \\
\text { medical } \\
\text { students }\end{array}$ & $\begin{array}{l}\text { Preclerkship HIV } \\
\text { elective }\end{array}$ & Thematic & $\begin{array}{l}\text { Enthusiasm for small } \\
\text { group sessions; clinical } \\
\text { observerships; community } \\
\text { agency placements; } \\
\text { diversity of topics covered }\end{array}$ & $\begin{array}{l}\text { Student-run initiatives can } \\
\text { supplement medical } \\
\text { curriculum content and } \\
\text { promote student } \\
\text { leadership and interest, } \\
\text { community partnerships, } \\
\text { and faculty mentorship. }\end{array}$ \\
\hline $\begin{array}{l}\text { Ellaway } \\
\text { et al., } \\
2014^{45}\end{array}$ & $\begin{array}{l}\text { Social, } \\
\text { intellectual }\end{array}$ & System & $\begin{array}{l}101 \text {; first-year } \\
\text { undergraduate } \\
\text { medical } \\
\text { students }\end{array}$ & $\begin{array}{l}\text { Mobile device } \\
\text { program }\end{array}$ & $\begin{array}{l}\text { Grounded } \\
\text { theory }\end{array}$ & $\begin{array}{l}\text { Mobile devices augment, } \\
\text { but are not replacements } \\
\text { for, laptop computers, and } \\
\text { mobile devices in medical } \\
\text { education are perceived } \\
\text { as a tool and source of } \\
\text { support }\end{array}$ & $\begin{array}{l}\text { Medical learners use } \\
\text { mobile devices depending } \\
\text { on the learning culture } \\
\text { and contexts of their } \\
\text { specific medical programs } \\
\text { and education ecologies. }\end{array}$ \\
\hline $\begin{array}{l}\text { Law et al., } \\
2019^{66}\end{array}$ & $\begin{array}{l}\text { Intellectual, } \\
\text { occupational }\end{array}$ & Individual & $\begin{array}{l}17 ; \\
\text { undergraduate } \\
\text { medical } \\
\text { students }\end{array}$ & $\begin{array}{l}\text { Computer } \\
\text { programming } \\
\text { certificate course }\end{array}$ & Thematic & $\begin{array}{l}\text { Value of the course; } \\
\text { potential application of } \\
\text { learning }\end{array}$ & $\begin{array}{l}\text { Computer science and } \\
\text { medicine would benefit } \\
\text { from enhanced 2-way } \\
\text { communication when } \\
\text { developing technology for } \\
\text { use in medicine. }\end{array}$ \\
\hline $\begin{array}{l}\text { Lynch } \\
\text { et al., } \\
2014^{68}\end{array}$ & $\begin{array}{l}\text { Social, } \\
\text { intellectual }\end{array}$ & Individual & $\begin{array}{l}4 ; \\
\text { undergraduate } \\
\text { medical } \\
\text { students }\end{array}$ & $\begin{array}{l}\text { Linking students } \\
\text { from North America } \\
\text { and Europe with a } \\
\text { peer-to-peer learning } \\
\text { approach }\end{array}$ & Thematic & $\begin{array}{l}\text { Peer connection; trust in } \\
\text { data veracity; aid to clinical } \\
\text { learning process }\end{array}$ & $\begin{array}{l}\text { Connecting students } \\
\text { across continents in a } \\
\text { community of peer-to- } \\
\text { peer learning encourages } \\
\text { peer cooperation with } \\
\text { potential to disseminate } \\
\text { key clinical learnings. }\end{array}$ \\
\hline $\begin{array}{l}\text { Welsher } \\
\text { et al., } \\
2018^{88}\end{array}$ & Intellectual & Individual & $\begin{array}{l}\text { 23; preclerkship } \\
\text { undergraduate } \\
\text { medical } \\
\text { students }\end{array}$ & $\begin{array}{l}\text { Video-based } \\
\text { observational } \\
\text { practice } \\
\text { communities that } \\
\text { augment simulation- } \\
\text { based skill education } \\
\text { and connect } \\
\text { geographically } \\
\text { distributed learners }\end{array}$ & Thematic & $\begin{array}{l}\text { Ease of use; technical } \\
\text { knowledge; versatile and } \\
\text { accessible; observational } \\
\text { tools beneficial to learning; } \\
\text { desire for more networked, } \\
\text { observational learning } \\
\text { activities }\end{array}$ & $\begin{array}{l}\text { Video-based } \\
\text { observational practice } \\
\text { communities are feasible } \\
\text { to support simulation- } \\
\text { based learning of clinical } \\
\text { skills in a distributed } \\
\text { group of health } \\
\text { professional trainees. }\end{array}$ \\
\hline
\end{tabular}




\begin{tabular}{|c|c|c|c|c|c|c|c|}
\hline Study & $\begin{array}{l}\text { Well-being } \\
\text { domaint }\end{array}$ & Level & $\begin{array}{l}\text { No. and type of } \\
\text { students }\end{array}$ & Intervention & Analysis & Themes or theory & $\begin{array}{l}\text { Author findings from } \\
\text { original study }\end{array}$ \\
\hline $\begin{array}{l}\text { Yeung } \\
\text { et al., } \\
2017^{90}\end{array}$ & $\begin{array}{l}\text { Social, } \\
\text { intellectual }\end{array}$ & Individual & $\begin{array}{l}\text { 20; second-year } \\
\text { undergraduate } \\
\text { medical } \\
\text { students }\end{array}$ & $\begin{array}{l}\text { Longitudinal } \\
\text { Students as } \\
\text { Teachers program }\end{array}$ & Thematic & $\begin{array}{l}\text { Program increased } \\
\text { perceived knowledge and } \\
\text { provided students with } \\
\text { opportunities to practice } \\
\text { teaching and to provide } \\
\text { and receive feedback, and } \\
\text { to reflect on their practice }\end{array}$ & $\begin{array}{l}\text { Early exposure to medical } \\
\text { education theories allows } \\
\text { opportunity to apply } \\
\text { theories practically } \\
\text { through ongoing teaching } \\
\text { and feedback sessions } \\
\text { that include reflective } \\
\text { exercises. }\end{array}$ \\
\hline \multicolumn{8}{|c|}{ Postgraduate medical students } \\
\hline $\begin{array}{l}\text { Campagna- } \\
\text { Vaillancourt } \\
\text { et al., } \\
2014^{34}\end{array}$ & Social & Program & $\begin{array}{l}45 ; \\
\text { otolaryngology- } \\
\text { head and neck } \\
\text { surgery }\end{array}$ & $\begin{array}{l}\text { Multiple Mini } \\
\text { Interview (MMI) for } \\
\text { the selection of } \\
\text { applicants to } \\
\text { residency }\end{array}$ & Thematic & $\begin{array}{l}\text { Meet more staff; less } \\
\text { stressful; multiple first } \\
\text { impressions; different } \\
\text { aspects of personality; } \\
\text { objective and fair; team } \\
\text { assessment }\end{array}$ & $\begin{array}{l}\text { Using the MMI for } \\
\text { admission to a residency } \\
\text { program has good } \\
\text { acceptability and } \\
\text { reliability, and is feasible. }\end{array}$ \\
\hline $\begin{array}{l}\text { Malhotra } \\
\text { et al., } \\
2008^{69}\end{array}$ & $\begin{array}{l}\text { Mental, } \\
\text { intellectual }\end{array}$ & Program & $\begin{array}{l}\text { 12; internal } \\
\text { medicine }\end{array}$ & $\begin{array}{l}\text { Mini Clinical } \\
\text { Evaluation Exercise }\end{array}$ & $\begin{array}{l}\text { Phenomeno- } \\
\text { logical }\end{array}$ & $\begin{array}{l}\text { Education; assessment; } \\
\text { exam preparation }\end{array}$ & $\begin{array}{l}\text { The mini Clinical } \\
\text { Evaluation Exercise is } \\
\text { anxiety provoking at first, } \\
\text { but may provide insight } \\
\text { into clinical competence } \\
\text { over time. }\end{array}$ \\
\hline $\begin{array}{l}\text { Myden } \\
\text { et al., } \\
2012^{74}\end{array}$ & $\begin{array}{l}\text { Intellectual, } \\
\text { occupational }\end{array}$ & Program & 6 ; orthopedics & $\begin{array}{l}\text { Computer-assisted } \\
\text { surgery simulations }\end{array}$ & Thematic & $\begin{array}{l}\text { Confidence; awareness; } \\
\text { deepening knowledge; } \\
\text { changed perspectives }\end{array}$ & $\begin{array}{l}\text { High-impact educational } \\
\text { interventions endorsing } \\
\text { cognitive flexibility } \\
\text { increases confidence, } \\
\text { changes awareness, and } \\
\text { deepens knowledge and } \\
\text { perspectives. }\end{array}$ \\
\hline $\begin{array}{l}\text { Sachedina } \\
\text { et al., } \\
2019^{77}\end{array}$ & Occupational & Individual & $\begin{array}{l}17 \text {; cardiac } \\
\text { critical care }\end{array}$ & $\begin{array}{l}\text { Code Blue } \\
\text { Simulation Program } \\
\text { (CBSP) }\end{array}$ & Thematic & $\begin{array}{l}\text { The CBSP is a useful tool } \\
\text { to help prepare residents } \\
\text { to serve as code blue } \\
\text { learners and the } \\
\text { authenticity of the CBSP } \\
\text { cases was useful }\end{array}$ & $\begin{array}{l}\text { The CBSP enhanced } \\
\text { resident preparedness. } \\
\text { Differences between } \\
\text { simulated and real codes } \\
\text { should be addressed to } \\
\text { enhance fidelity. }\end{array}$ \\
\hline $\begin{array}{l}\text { Sukhera } \\
\text { et al., } \\
2018^{83}\end{array}$ & Mental & System & 10; psychiatry & $\begin{array}{l}\text { Mental illness } \\
\text { implicit association } \\
\text { test }\end{array}$ & $\begin{array}{l}\text { Grounded } \\
\text { theory }\end{array}$ & $\begin{array}{l}\text { Vulnerability provoked } \\
\text { tension between personal } \\
\text { and professional identities } \\
\text { reconciled through striving } \\
\text { for ideal while } \\
\text { acknowledging the actual }\end{array}$ & $\begin{array}{l}\text { Addressing implicit bias } \\
\text { among health } \\
\text { professionals is } \\
\text { influenced by the process } \\
\text { of recognizing and } \\
\text { managing biases. }\end{array}$ \\
\hline $\begin{array}{l}\text { Tait et al., } \\
2013^{84}\end{array}$ & $\begin{array}{l}\text { Mental, } \\
\text { intellectual, } \\
\text { occupational }\end{array}$ & Individual & $\begin{array}{l}7 \text {; family } \\
\text { medicine, } \\
\text { psychiatry }\end{array}$ & $\begin{array}{l}\text { The Dignity } \\
\text { Interview }\end{array}$ & Thematic & $\begin{array}{l}\text { Experience of the } \\
\text { interview; patient as } \\
\text { teacher; residents } \\
\text { reflecting on their own } \\
\text { lives; resident reflections } \\
\text { on palliative or end-of-life } \\
\text { care education; physician } \\
\text { role in conflict }\end{array}$ & $\begin{array}{l}\text { Conversations with dying } \\
\text { patients and soliciting a } \\
\text { patient's story are poorly } \\
\text { taught and modelled in } \\
\text { medical education. }\end{array}$ \\
\hline $\begin{array}{l}\text { Tan et al., } \\
2013^{85}\end{array}$ & $\begin{array}{l}\text { Social, } \\
\text { occupational }\end{array}$ & Program & $\begin{array}{l}\text { 130; family } \\
\text { medicine }\end{array}$ & $\begin{array}{l}\text { Online virtual patient } \\
\text { clinical case in } \\
\text { palliative care }\end{array}$ & Thematic & $\begin{array}{l}\text { Useful content; } \\
\text { beneficial teaching } \\
\text { modality; realism of } \\
\text { case; awkward } \\
\text { navigation; worried } \\
\text { about missing key points } \\
\text { in the case }\end{array}$ & $\begin{array}{l}\text { The online virtual patient } \\
\text { case in palliative care is a } \\
\text { useful teaching tool to } \\
\text { address need for } \\
\text { increased formal palliative } \\
\text { care experience in } \\
\text { medical education. }\end{array}$ \\
\hline
\end{tabular}

and program affirmation of the role of being a learner in a medical school, and systems that favour attributing meaning to being a learner. Qualitative studies provided insight into catalyzing the shift from reducing manifestations of distress to proactively optimizing well-being.

\section{Interpretation}

We conducted a scoping review of published interventions conducted in Canadian medical schools to improve the well-being of medical learners. Our review shows that many Canadian 


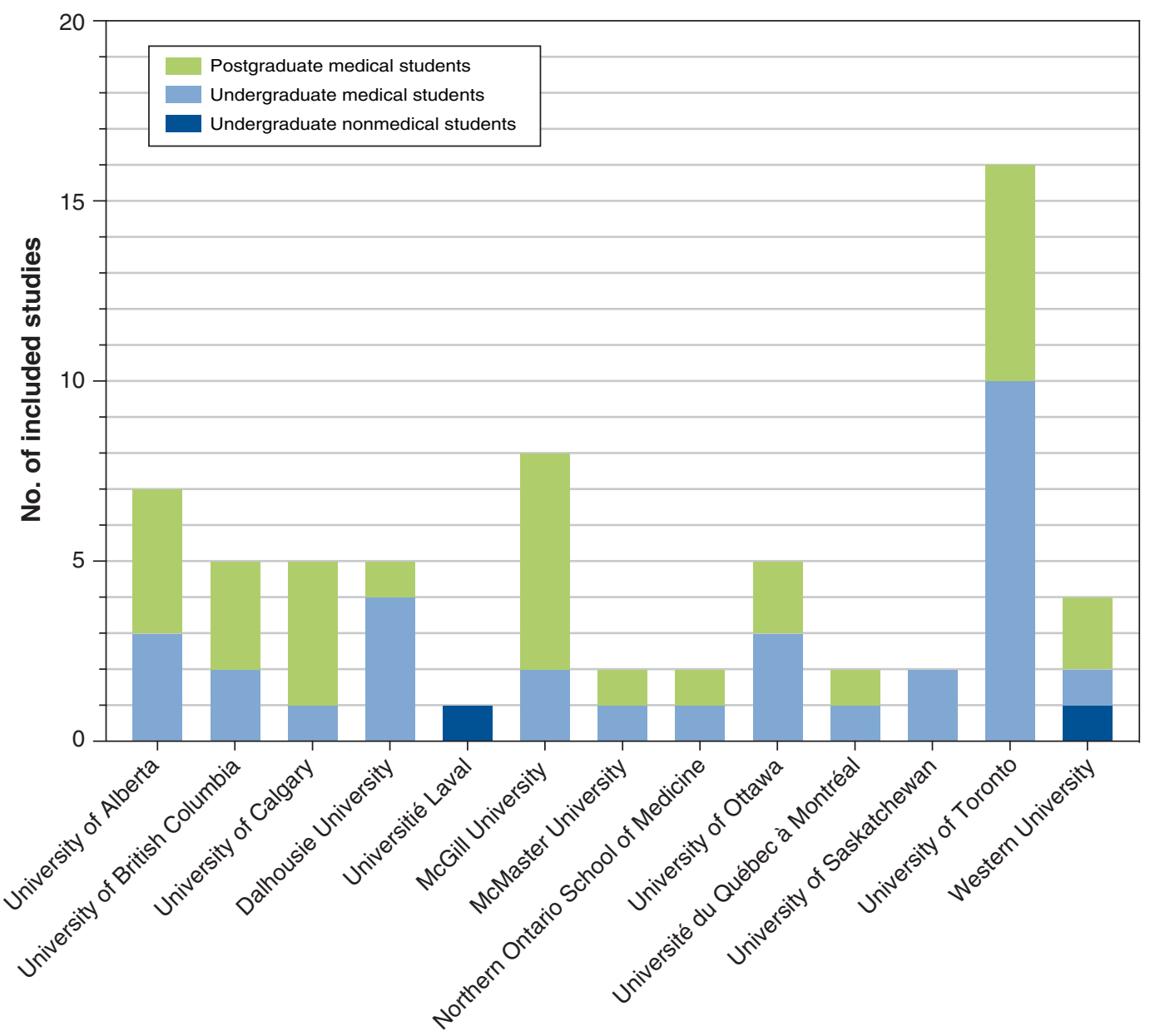

Medical school

Figure 2: Medical schools and learners represented among included studies.

medical schools address intellectual, occupational and social well-being through interventions targeted to individual medical learners and their respective programs, within the medical education system. The well-being of graduate students in health sciences programs does not appear to have been addressed through targeted interventions. Across all medical learners in Canada, mental and physical well-being is an important area that requires further exploration.

Few included studies used formal faculty adviser or mentor programs as a method to promote social well-being. Mentorship is an interactive process to encourage learning and development, grounded in social learning principles, ${ }^{93,94}$ that has been used extensively in medical schools in the United States. ${ }^{12}$ Academic mentors model the importance of key components of social well-being - inclusion, diversity and professionalism - in medical education. ${ }^{95}$ Formal mentorship programs that are integrated with curricular content can be used to offer career guidance to graduate science researchers, ${ }^{96,97}$ or to develop clinical skills among medical students ${ }^{98}$ and resident physicians. ${ }^{99}$ Mentorship programs for social well-being report high satisfaction, ${ }^{100,101}$ career promotion, ${ }^{102}$ improved clinical performance ${ }^{103}$ and patient safety. ${ }^{104} \mathrm{We}$ encourage Canadian medical schools to consider social wellbeing among their medical learners.

Barriers to mental health treatment for medical learners are common ${ }^{105,106}$ and important to recognize for effective mental health interventions. ${ }^{107,108}$ Learners with mental health disorders and symptoms are often undiagnosed and undertreated. ${ }^{109}$ We found a gap in increasing access and reducing stigma around mental health interventions within Canadian medical schools. In 2019, Wilkes and colleagues surveyed 69 undergraduate medical students and reported that $83 \%$ of students considered medical education a source of stress, and $70 \%$ met criteria for exhaustion; however, only $36 \%$ of students reported seeing a mental health professional to address mental health concerns. ${ }^{110}$ There is a need for formal programs focused on mental well-being, inclusive of increasing awareness, reducing stigma and improving access to mental 


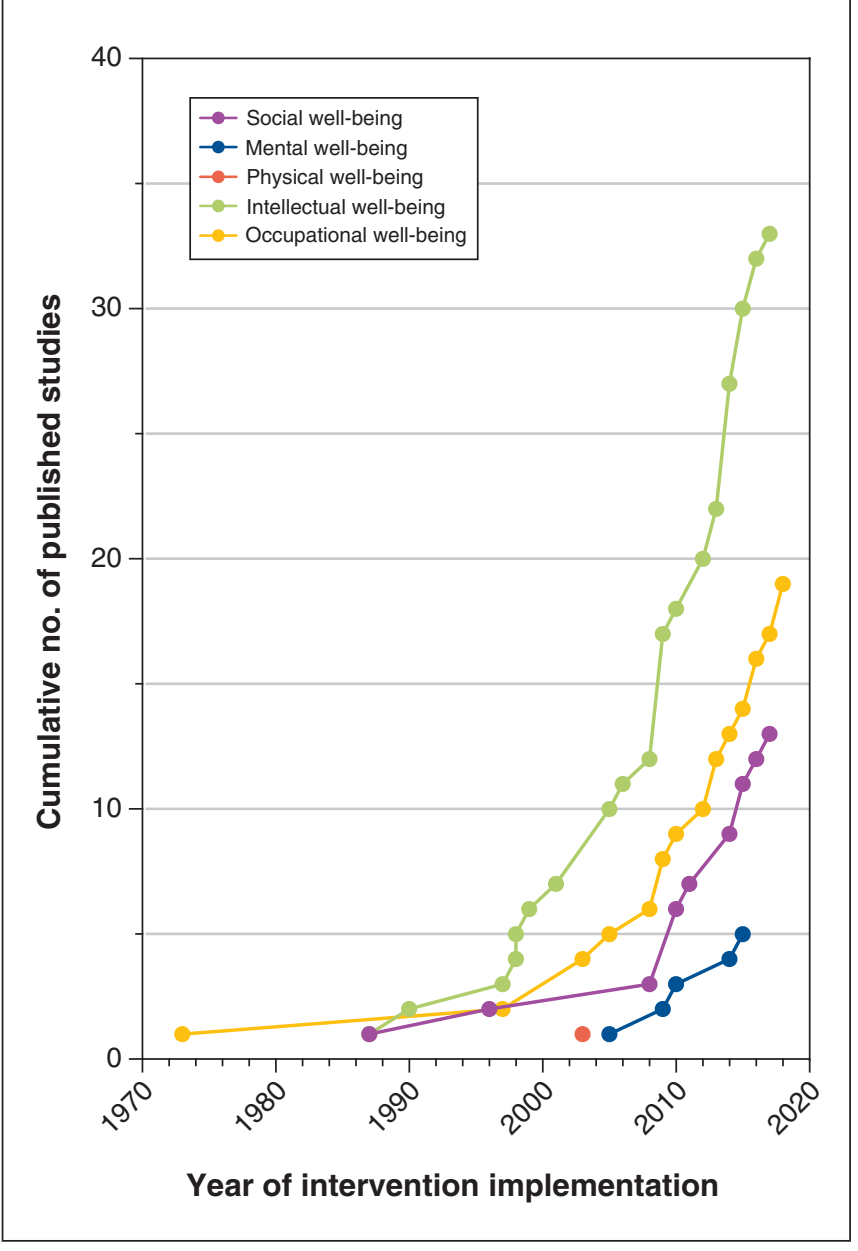

Figure 3: Cumulative number of published studies on interventions for medical learner well-being.

health services. Although such programs are associated with lower depression and suicidal ideation rates in the United States, the effectiveness of this approach in Canadian medical schools is unknown. ${ }^{111}$

We found a scarcity of interventions aimed to improve the physical well-being of medical learners. ${ }^{12}$ Physical wellbeing does not have comparable widespread acceptance as an aspect of physician well-being. ${ }^{113,114}$ Adherence to various dimensions of physical well-being is low among undergraduate medical education students. ${ }^{115}$ In an online cross-sectional survey of fourth-year medical students at the University of British Columbia, Holtz and colleagues showed that those who perceived exercise counselling to be highly important to clinical practice participated in daily physical activity. ${ }^{116}$ Although it may be hubristic to suggest interventions to improve learner physical well-being will improve patient outcomes ${ }^{117}$ we contend that encouraging physical well-being should be a core component in developing competent and professional future physicians. ${ }^{118}$

Many interventions in Canadian medical schools promote collectives of learners to encourage a collaborative state of mind rather than peer-to-peer competition. All but 2 Canadian medical schools have adopted a pass/fail grading system for medical education. ${ }^{119} \mathrm{~A}$ pass/fail system has been shown to improve intellectual well-being, ${ }^{120}$ enhancing teamwork among learners ${ }^{121}$ without negative impact on academic performance. ${ }^{122}$ Pass/fail grading systems, complemented by standards-based evaluations, are a step along the continuum to recognizing learners as professionals, enhancing intellectual well-being and preparing medical students for life as enduring learners. ${ }^{123,124}$ Further, many studies reported that medical learners have higher satisfaction and greater achievement of knowledge-related outcomes when skills are taught in condensed workshops, ranging from 2 hours,$^{59}$ to 5 days,$^{41}$ to 2 weeks. ${ }^{51}$ More research is needed to understand massed versus dispersed learning to maximize intellectual well-being.

Occupational well-being is an increasingly researched area in Canadian medical schools, particularly in resident trainees. ${ }^{125}$ Compared with physicians, residents in Canada have a $48 \%$ increased risk of burnout, $95 \%$ increased risk of depression and $72 \%$ increased risk of suicidal thoughts. ${ }^{126}$ Residency programs play a predominant role in the occupational wellbeing of residents; medical leaders have stressed the need for universities to make occupational well-being a core competency of medicine by redesigning medical programs. ${ }^{127} \mathrm{We}$ found many interventions that aimed to improve occupational well-being at the program and system level by addressing culture, learning and work environments; however, more research is needed to ensure that efficacious interventions are effectively implemented in a contextually adaptive manner to respond to individual learner needs.

We suggest 3 key directions when considering future interventions. First, positive psychological outcomes are important, ${ }^{128}$ given that positive psychological adaptations evolve to meet the demands of stressful experiences. ${ }^{129,130}$ Highly resilient individuals are known to cultivate positive adaptations proactively; ${ }^{131,132}$ it is unknown whether or not positive psychological adaptations are by-products of interventions or whether they improve coping. Future interventions for improved mental well-being should consider the aggregate of negative and positive mental well-being outcomes.

Second, the well-being of graduate science education students in Canada has not been considered widely. Scientific research is an important element in graduate science education programs, and learners conducting scientific research may face unique well-being challenges. ${ }^{133,134}$ In Canada, the integrative $\mathrm{MD}-\mathrm{PhD}$ program is a popular approach for training physician-scientists, ${ }^{135}$ representing a substantial investment of institutional, federal and societal resources. ${ }^{136}$ Medical schools might consider interventions for all learners conducting scientific medical research to augment their success as future investigators.

Lastly, process evaluation is needed to assess the implementation of interventions and outcomes over time. Though most studies reported positive improvements, it is possible that interventions were not reliably delivered or consistently adhered to. ${ }^{137}$ As others have mentioned, ${ }^{12}$ we suggest that intervention evaluations include the study of sequential 


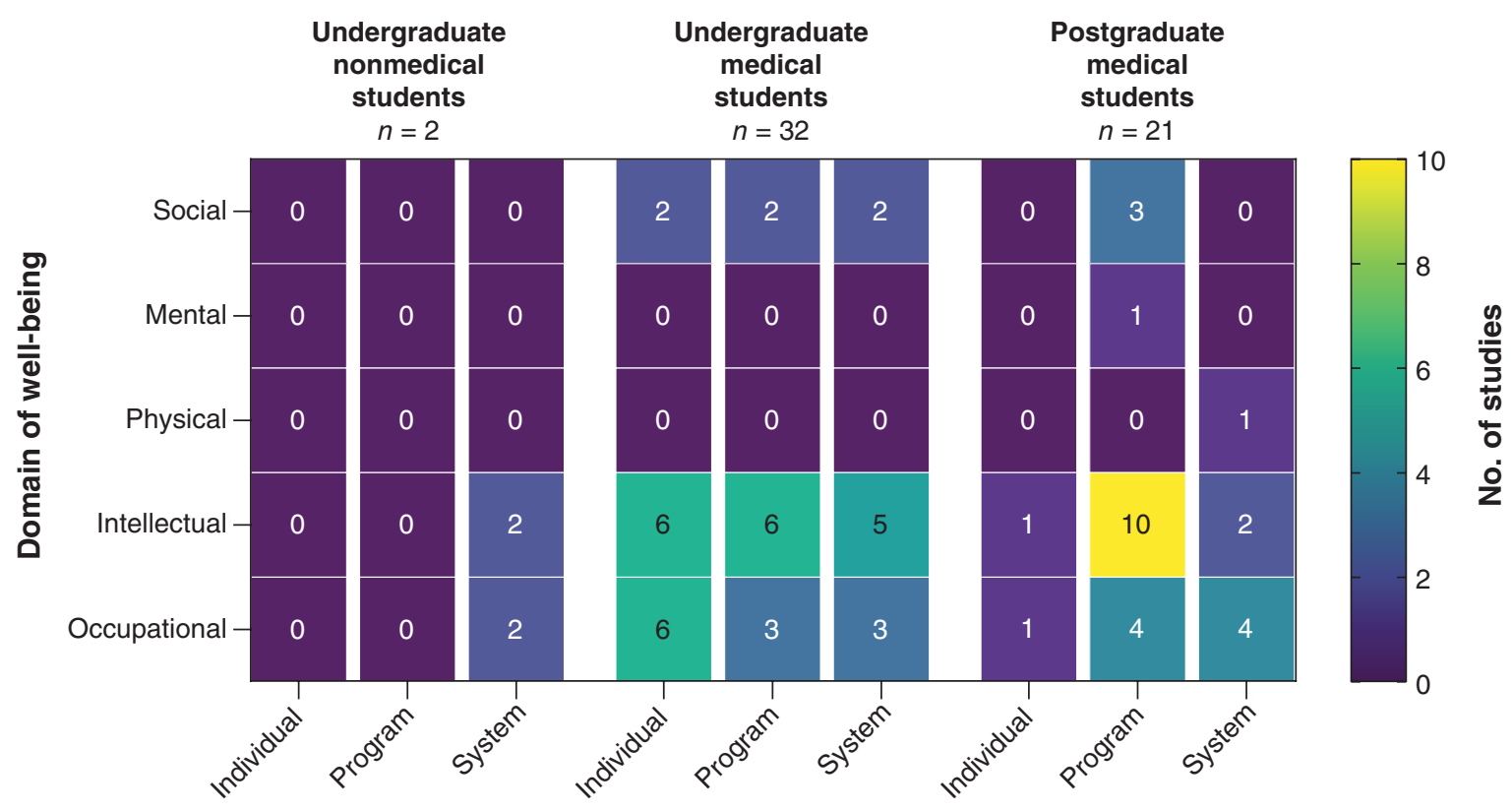

Level of intervention

Figure 4: Number of studies that reported significantly positive effects of well-being interventions by well-being domain, level of intervention and type of learner. Note: One level of intervention was recorded from each included study. More than one well-being domain could be recorded from a single study.

phases of implementation to determine synergies among well-being domains associated with improvement in learner well-being. Interventions may have adverse effects that should be weighed against potential benefits, ${ }^{138}$ and success during one stage of training may not be helpful during the next stage of training. ${ }^{139}$

\section{Limitations}

The protocol for our review was not registered; we included only primary studies and did not search grey literature, which may fill gaps we identified or report interventions with negative outcomes. Our definition of medical learner is not a validated definition. ${ }^{20}$ We categorized studies based on 5 domains of well-being, but there may be other well-being domains related to medical learning (e.g., spirituality). ${ }^{140} \mathrm{We}$ found authors nearly exclusively reported successes and few failures, which suggests positive publication bias. Given the multidimensional constructs of interventions, it was not possible to determine specific components of interventions associated with more favourable outcomes. The lack of a universal definition for learner well-being added complexity to study selection, but our broad inclusion criteria allowed us to produce a comprehensive summary of literature. Our review was limited to medical learners in Canada and the included studies did not report on subpopulations of learners (e.g., Indigenous students, international students). We were unable to comment on different race and ethnocultural factors influencing the learning experience. ${ }^{141}$

\section{Conclusion}

Interventions to improve the well-being of medical learners in Canadian medical schools vary. Many Canadian medical schools have addressed intellectual, occupational and social well-being through interventions targeted to individual medical learners, their medical learning programs or the educational or health care systems. The well-being of graduate students in health sciences programs does not appear to have been addressed through targeted interventions. Across all medical learners in Canada, mental and physical well-being is an important area for further exploration. Comprehensive and inclusive interventions aimed to improve well-being for medical learners in Canada are needed.

\section{References}

1. Jennings ML, Slavin SJ. Resident wellness matters: optimizing resident education and wellness through the learning environment. Acad Med 2015; 90:1246-50.

2. Ripp JA, Privitera MR, West CP, et al. Well-being in graduate medical education: a call for action. Acad Med 2017;92:914-7.

3. Slavin SJ, Chibnall JT. Finding the why, changing the how: improving the mental health of medical students, residents, and physicians. Acad Med 2016;91:1194-6.

4. Tawfik DS, Profit J, Morgenthaler TI, et al. Physician burnout, well-being, and work unit safety grades in relationship to reported medical errors. Mayo Clin Proc 2018;93:1571-80.

5. Vogel L. Physician health charter calls on health systems, organizations to share responsibility for burnout. CMA7 2018;190:E812-3.

6. Vogel L. Medical education needs reform to improve student well-being and reduce burnout, say experts. CMA7 2018;190:E1426-7.

7. Brazeau CMLR, Shanafelt T, Durning SJ, et al. Distress among matriculating medical students relative to the general population. Acad Med 2014; 89:1520-5. 
8. Dyrbye LN, West CP, Satele D, et al. Burnout among U.S. medical students, residents, and early career physicians relative to the general U.S. population. Acad Med 2014;89:443-51.

9. Roberts DL, Shanafelt TD, Dyrbye LN, et al. A national comparison of burnout and work-life balance among internal medicine hospitalists and outpatient general internists. 7 Hosp Med 2014;9:176-81.

10. Eleftheriades R, Fiala C, Pasic MD. The challenges and mental health issues of academic trainees. F1000Res 2020;9:104

11. Student affairs. Ottawa: Canadian Federation of Medical Students. Available: www.cfms.org/what-we-do/student-affairs/ (accessed 2021 Mar. 19).

12. Wasson LT, Cusmano A, Meli L, et al. Association between learning environment interventions and medical student well-being: a systematic review. 7AMA 2016;316:2237-52.

13. Kötter T, Fuchs S, Heise M, et al. What keeps medical students healthy and well? A systematic review of observational studies on protective factors for health and well-being during medical education. BMC Med Educ 2019;19:94.

14. Kassam A, Ellaway R. Acknowledging a holistic framework for learner wellness: the human capabilities approach. Acad Med 2020;95:9-10.

15. Nussbaum MC. Women and human development: the capabilities approach. Cambridge (UK): Cambridge University Press; 2000.

16. Roscoe LJ. Wellness: a review of theory and measurement for counselors. 7 Couns Dev 2009;87:216-26.

17. Kassam A, Cowan M, Topps M. Lessons learned to aid in developing fatigue risk management plans for resident physicians. Teach Learn Med 2019; 31:136-45.

18. Joanna Briggs Institute. The Joanna Briggs Institute best practice information sheet: the effectiveness of pelvic floor muscle exercises on urinary incontinence in women following childbirth. Nurs Health Sci 2011;13:378-81.

19. Arksey H, O'Malley L. Scoping studies: towards a methodological framework. Int 7 Soc Res Methodol 2005;8:19-32.

20. Terminology in Medical Education Project. Ottawa: The Royal College of Physicians and Surgeons of Canada. Available: www.royalcollege.ca/rcsite/ educational-initiatives/terminology-medical-education-project-e (accessed 2020 June 16).

21. Cherak S, Brown A, Kachra R, et al. Exploring the impact of the COVID-19 pandemic on medical learner wellness: a needs assessment for the development of learner wellness interventions. Can Med Educ 7 2021;12:54-69.

22. Bewick B, Koutsopoulou G, Miles J, et al. Changes in undergraduate students' psychological well-being as they progress through university. Stud High Educ 2010;35:633-45.

23. Thomas J, Harden A. Methods for the thematic synthesis of qualitative research in systematic reviews. BMC Med Res Methodol 2008;8:45.

24. Lewin S, Bohren M, Rashidian A, et al. Applying GRADE-CERQual to qualitative evidence synthesis findings-paper 2: how to make an overall CERQual assessment of confidence and create a Summary of Qualitative Findings table. Implement Sci 2018;13(Suppl 1):10.

25. O'Cathain A, Goode J, Drabble SJ, et al. Getting added value from using qualitative research with randomized controlled trials: a qualitative interview study. Trials 2014;15:215

26. Petticrew M, Rehfuess E, Noyes J, et al. Synthesizing evidence on complex interventions: how meta-analytical, qualitative, and mixed-method approaches can contribute. 7 Clin Epidemiol 2013;66:1230-43.

27. Ali J. The Trauma Evaluation and Management (TEAM) teaching module: its role for senior medical students in Canada. Can F Surg 2003;46:99-102.

28. Baird R, Poenaru D, Ganey M, et al. Partnership in fellowship: comparative analysis of pediatric surgical training and evaluation of a fellow exchange between Canada and Kenya. 7 Pediatr Surg 2016;51:1704-10.

29. Bland E, Oppenheimer L, Brisson-Carroll G, et al. Influence of an educational program on medical students' attitudes to substance use disorders in pregnancy. Am 7 Drug Alcohol Abuse 2001;27:483-90.

30. Brown A, Nidumolu A, Stanhope A, et al. Can first-year medical students acquire quality improvement knowledge prior to substantial clinical exposure? A mixed-methods evaluation of a pre-clerkship curriculum that uses education as the context for learning. BMF Qual Saf 2018;27:576-82.

31. Burbridge B, Kalra N, Malin G, et al. University of Saskatchewan Radiology Courseware (USRC): an assessment of its utility for teaching diagnostic imaging in the medical school curriculum. Teach Learn Med 2015;27:91-8.

32. Byszewski A, Bezzina K, Latrous M. What kind of doctor do you want to be? Geriatric medicine podcast as a career planning resource. BioMed Res Int 2017:2017:6183148.

33. Cadieux DC, Lingard L, Kwiatkowski D, et al. Challenges in translation: lessons from using business pedagogy to teach leadership in undergraduate medicine. Teach Learn Med 2017;29:207-15.

34. Campagna-Vaillancourt M, Manoukian J, Razack S, et al. Acceptability and reliability of multiple mini interviews for admission to otolaryngology residency. Laryngoscope 2014;124:91-6.

35. Cassidy-Smith TN, Kilgannon JH, Nyce AL, et al. Impact of a teaching attending physician on medical student, resident, and faculty perceptions and satisfaction. CFEM 2011;13:259-66.

36. Chew D, Jaworsky D, Thorne J, et al. Development, implementation, and evaluation of a student-initiated undergraduate medical education elective in HIV care. Med Teach 2012;34:398-403.
37. Cleave-Hogg D, Morgan PJ. Experiential learning in an anaesthesia simulation centre: analysis of students' comments. Med Teach 2002;24:23-6.

38. Crutcher RA, Then K, Edwards A, et al. Multi-professional education in diabetes. Med Teach 2004;26:435-43.

39. D'Urzo KA, Flood SM, Baillie C, et al. Evaluating the implementation and impact of a motivational interviewing workshop on medical student knowledge and social cognitions towards counseling patients on lifestyle behaviors. Teach Learn Med 2020;32:218-30.

40. Dore KL, Kreuger S, Ladhani M, et al. The reliability and acceptability of the Multiple Mini-Interview as a selection instrument for postgraduate admissions. Acad Med 2010;85(Suppl):S60-3.

41. Downar J, Krizova A, Ghaffar O, et al. Neuroimaging week: a novel, engaging, and effective curriculum for teaching neuroimaging to junior psychiatric residents. Acad Psychiatry 2010;34:119-24.

42. Dumont S, Brière N, Morin D, et al. Implementing an interfaculty series of courses on interprofessional collaboration in prelicensure health science curriculums. Educ Health (Abingdon) 2010;23:395.

43. Duque G, Gold S, Bergman H. Early clinical exposure to geriatric medicine in second-year medical school students: the McGill experience. 7 Am Geriatr Soc 2003;51:544-8.

44. Elharram M, Dinh T, Lalande A, et al. Global health values of a multidirectional near peer training program in surgery, pathology, anatomy, research methodology, and medical education for Haitian, Rwandan, and Canadian medical students. Ann Glob Health 2017;83:274-80.

45. Ellaway RH, Fink P, Graves L, et al. Left to their own devices: medical learners' use of mobile technologies. Med Teach 2014;36:130-8.

46. Ens A, Janze K, Palmert MR. Development of an online learning module to improve pediatric residents' confidence and knowledge of the pubertal examination. $\mathcal{F}$ Adolesc Health 2017;60:292-8.

47. Fabreau G, Elliott M, Khanna S, et al. Shifting perceptions: a pre-post study to assess the impact of a senior resident rotation bundle. BMC Med Educ 2013;13:115.

48. Fairchild A, Watanabe S, Chambers C, et al. Initiation of a multidisciplinary summer studentship in palliative and supportive care in oncology. 7 Multidiscip Healthc 2012;5:231-9.

49. Finley JP, Beland MJ, Boutin C, et al. A national network for the tele-education of Canadian residents in pediatric cardiology. Cardiol Young 2001; 11:526-31.

50. Garg A, Buckman R, Kason Y. Teaching medical students how to break bad news. CMA7 1997;156:1159-64

51. Gawad N, Moussa F, Christakis GT, et al. Planting the 'SEAD': early comprehensive exposure to surgery for medical students. F Surg Educ 2013; 70:487-94.

52. Gibson J, Nouyen D, Davidson J, et al. Effectiveness of an educational handbook in improving psychiatry resident knowledge of second-generation antipsychotics. Acad Psychiatry 2015;39:154-9.

53. Gilic F, Sempowski I, Blagojevic A, et al. P046: The "Nightmares" course: effective simulation-based acute care training method for family medicine residents [abstract]. Can Fam Physician 2015;61:S52.

54. Grabovac A, McKenna M. Pilot study and evaluation of postgraduate course on "the interface between spirituality, religion and psychiatry". Acad Psychiatry 2008;32:332-7.

55. Greene B, Head L, Gawad N, et al. Surgical exploration and discovery program: inaugural involvement of otolaryngology - head and neck surgery. $\mathcal{F}$ Otolaryngol Head Neck Surg 2015;44:3.

56. Hanna WC, Mulder DS, Fried GM, et al. Training future surgeons for management roles: the resident-surgeon-manager conference. Arch Surg 2012; 147:940-4.

57. Harding SR, D'Eon MF. Using a Lego-based communications simulation to introduce medical students to patient-centered interviewing. Teach Learn Med 2001;13:130-5

58. Haupt TS, Dow T, Smyth M, et al. Medical student exposure to radiation oncology through the Pre-clerkship Exploration Program (PREP): effect on career interest and understanding of radiation oncology. Radiother Oncol 2019;139(Suppl 1):S33.

59. Ibrahim GM, Hoffart S, Lam RA, et al. Think global, act local: medical students contextualize global health education. Educ Health (Abingdon) 2014; 27:55-8.

60. James MT, Mintz MJ, McLaughlin K. Evaluation of a multifaceted "residentas-teacher" educational intervention to improve morning report. BMC Med Educ 2006;6:20.

61. Jamniczky HA, Cotton D, Paget M, et al. Cognitive load imposed by ultrasound-facilitated teaching does not adversely affect gross anatomy learning outcomes. Anat Sci Educ 2017;10:144-51.

62. Jefferies A, Shah V. Clinicians prefer simple educational tools for implementing practice change. Med Teach 2011;33:e602-6.

63. Kanagasabai T, Muharuma L, McGuire J, et al. Evidence-based strategies to improve immunization compliance of postgraduate medical trainees at large academic-medical facilities. Healthc Q 2007;10:81-6.

64. Laidlaw TS, MacLeod H, Kaufman DM, et al. Implementing a communication skills programme in medical school: needs assessment and programme change. Med Educ 2002;36:115-24. 
65. Law M, Rapoport MJ, Seitz D, et al. Evaluation of a national online educational program in geriatric psychiatry. Acad Psychiatry 2016;40:923-7.

66. Law M, Veinot P, Campbell J, et al. Computing for medicine: Can we prepare medical students for the future? Acad Med 2019;94:353-7.

67. Livingston MC, Bass S, Emery AW, et al. Six medical students in a community hospital. Can Med Assoc 7 1973;109:1013-6.

68. Lynch NP, Cil T, Lehane E, et al. Transatlantic peer-to-peer learning: an initial feasibility analysis. Surg Innov 2014;21:643-8.

69. Malhotra S, Hata R, Courneya C-A. Internal medicine residents' perceptions of the Mini-Clinical Evaluation Exercise. Med Teach 2008;30:414-9.

70. McKendy KM, Posel N, Fleiszer DM, et al. A learner-created virtual patient curriculum for surgical residents: successes and failures. 7 Surg Educ 2016;73:559-66.

71. McMillan HJ, Writer H, Moreau KA, et al. Lumbar puncture simulation in pediatric residency training: improving procedural competence and decreasing anxiety. BMC Med Educ 2016;16:198.

72. Meterissian S, Liberman M, McLeod P. Games as teaching tools in a surgical residency. Med Teach 2007;29:e258-60.

73. Morgan PJ, Cleave-Hogg D. A Canadian simulation experience: faculty and student opinions of a performance evaluation study. Br F Anaesth 2000;85:779-81.

74. Myden CA, Anglin C, Kopp GD, et al. Computer-assisted surgery simulations and directed practice of total knee arthroplasty: educational benefits to the trainee. Comput Aided Surg 2012;17:113-27.

75. Posluns E, Shafir MS, Keystone JS, et al. Rewarding medical teaching excellence in a major Canadian teaching hospital. Med Teach 1990;12:13-22.

76. Roach VA, Brandt MG, Moore CC, et al. Is three-dimensional videography the cutting edge of surgical skill acquisition? Anat Sci Educ 2012;5:138-45.

77. Sachedina AK, Blissett S, Remtulla A, et al. Preparing the next generation of code blue leaders through simulation: What's missing? Simul Healthc 2019; 14:77-81.

78. Shapiro SM, Lancee WJ, Richards-Bentley CM. Evaluation of a communication skills program for first-year medical students at the University of Toronto. BMC Med Educ 2009;9:11.

79. Sheppard E, Smyth M, Dow T, et al. The effect of a 2-week pre-clerkship residency exploration program on specialty interest and understanding of physical medicine and rehabilitation. Arch Rebabil Res Clin Transl 2019; 2:100035.

80. Skoll MA, Dueckman R, Liston R. Fostering harmony in labor and delivery: a nursing preceptorship for clinical clerks. Obstet Gynecol 2006;108:157-61.

81. Smyth M, Toguri JT, Dow T, et al. Medical student exposure to anesthesiology through the Pre-clerkship Residency Exploration Program: impact on career interest and understanding of anesthesiology. Can 7 Anaesth 2019; 66:1126-8.

82. Sternszus R, Steinert $Y$, Bhanji F, et al. Evaluating a novel resident role-modelling programme. Clin Teach 2018;15:252-7.

83. Sukhera J, Wodzkinski M, Teunissen PW, et al. Striving while accepting: exploring the relationship between identity and implicit bias recognition and management. Acad Med 2018;93(11S Association of American Medical Colleges Learn Serve Lead: Proceedings of the 57th Annual Research in Medical Education Sessions):S82-8.

84. Tait GR, Hodges BD. Residents learning from a narrative experience with dying patients: a qualitative study. Adv Health Sci Educ Theory Pract 2013;18:727-43.

85. Tan A, Ross SP, Duerksen K. Death is not always a failure: outcomes from implementing an online virtual patient clinical case in palliative care for family medicine clerkship. Med Educ Online 2013;18:22711.

86. Telner D, Bujas-Bobanovic $M$, Chan D, et al. Game-based versus traditional case-based learning: comparing effectiveness in stroke continuing medical education. Can Fam Physician 2010;56:e345-51.

87. Turner SR, White J, Poth C, et al. Preparing students for clerkship: a resident shadowing program. Acad Med 2012;87:1288-91.

88. Welsher A, Rojas D, Khan Z, et al. The application of observational practice and educational networking in simulation-based and distributed medical education contexts. Simul Healthc 2018;13:3-10

89. Willett TG, Kirlew M, Cardinal P, et al. An evaluation of the Acute Critical Events Simulation (ACES) course for family medicine residents. Can 7 Rural Med 2011;16:89-95.

90. Yeung C, Friesen F, Farr S, et al. Development and implementation of a longitudinal students as teachers program: participant satisfaction and implications for medical student teaching and learning. BMC Med Educ 2017;17:28.

91. Zahrai A, Chahal J, Stojimirovic D, et al. Quality of life and educational benefit among orthopedic surgery residents: a prospective, multicentre comparison of the night float and the standard call systems. Can 7 Surg 2011; 54:25-32.

92. Gawad N, Moussa F, Christakis G, et al. Planting the 'SEAD': early comprehensive exposure to surgery for medical students. F Surg Educ 2013; 70:487-94.

93. Gagliardi AR, Webster F, Straus SE. Designing a knowledge translation mentorship program to support the implementation of evidence-based innovations. BMC Health Serv Res 2015;15:198.

94. Gagliardi AR, Wright FC, Anderson MAB, et al. The role of collegial interaction in continuing professional development. 7 Contin Educ Health Prof 2007;27:214-9.
95. Rose GL, Rukstalis MR, Schuckit MA. Informal mentoring between faculty and medical students. Acad Med 2005;80:344-8.

96. Straus SE, Sackett DL. Clinician-trialist rounds: 10. Mentoring - part 4 attributes of an effective mentor. Clin Trials 2012;9:367-9.

97. Straus SE, Straus C, Tzanetos K. International Campaign to Revitalise Academic Medicine. Career choice in academic medicine: systematic review. 7 Gen Intern Med 2006;21:1222-9.

98. McKenna AM, Straus SE. Charting a professional course: a review of mentorship in medicine. 7 Am Coll Radiol 2011;8:109-12.

99. Straus SE, Johnson MO, Marquez C, et al. Characteristics of successful and failed mentoring relationships: a qualitative study across two academic health centers. Acad Med 2013;88:82-9.

100. Sambunjak D, Straus SE, Marusic A. A systematic review of qualitative research on the meaning and characteristics of mentoring in academic medicine. 7 Gen Intern Med 2010;25:72-8.

101. Sambunjak D, Straus SE, Marusić A. Mentoring in academic medicine: a systematic review. FAMA 2006;296:1103-15.

102. Allen TD, Eby LT, Lentz E. Mentorship behaviors and mentorship quality associated with formal mentoring programs: closing the gap between research and practice. 7 Appl Psychol 2006;91:567-78.

103. Sastre EA, Burke EE, Silverstein E, et al. Improvements in medical school wellness and career counseling: a comparison of one-on-one advising to an Advisory College Program. Med Teach 2010;32:e429-35.

104. Ficklin FL, Hazelwood JD, Carter JE, et al. Evaluation of a small-group support program for first-year medical students. 7 Med Educ 1983;58:817-9.

105. Plaut SM, Maxwell SA, Seng L, et al. Mental health services for medical students: perceptions of students, student affairs deans, and mental health providers. Acad Med 1993;68:360-5.

106. Gentile JP, Roman B. Medical student mental health services: psychiatrists treating medical students. Psychiatry (Edgmont) 2009;6:38-45.

107. Knaak S, Mantler E, Szeto A. Mental illness-related stigma in healthcare: barriers to access and care and evidence-based solutions. Healthc Manage Forum 2017;30:111-6.

108. Dyrbye LN, Eacker A, Durning SJ, et al. The impact of stigma and personal experiences on the help-seeking behaviors of medical students with burnout. Acad Med 2015;90:961-9.

109. Givens JL, Tjia J. Depressed medical students' use of mental health services and barriers to use. Acad Med 2002;77:918-21.

110. Wilkes C, Lewis T, Brager N, et al. Wellbeing and mental health amongst medical students in Canada. Int Rev Psychiatry 2019;31:584-7.

111. Thompson D, Goebert D, Takeshita J. A program for reducing depressive symptoms and suicidal ideation in medical students. Acad Med 2010;85:1635-9.

112. Tremblay MS, Warburton DER, Janssen I, et al. New Canadian physical activity guidelines. Appl Physiol Nutr Metab 2011;36:36-46, 47-58.

113. Warburton DER, Nicol CW, Bredin SSD. Prescribing exercise as preventive therapy. CMA7 2006;174:961-74.

114. Kennedy MF, Meeuwisse WH. Exercise counselling by family physicians in Canada. Prev Med 2003;37:226-32.

115. Khan R, Rehman R, Baig M, et al. Dimensions of physical wellness among medical students of public and private medical colleges in Pakistan. Saudi Med 7 2015;36:754-8.

116. Holtz KA, Kokotilo KJ, Fitzgerald BE, et al. Exercise behaviour and attitudes among fourth-year medical students at the University of British Columbia. Can Fam Physician 2013;59:e26-32.

117. Frank E, Tong E, Lobelo F, et al. Physical activity levels and counseling practices of U.S. medical students. Med Sci Sports Exerc 2008;40:413-21.

118. Vallance JK, Wylie M, MacDonald R. Medical students' self-perceived competence and prescription of patient-centered physical activity. Prev Med 2009;48:164-6.

119. Glauser W. Quebec medical schools slow to adopt pass/fail system. CMAf 2017;189:E1499-500.

120. Reed DA, Shanafelt TD, Satele DW, et al. Relationship of pass/fail grading and curriculum structure with well-being among preclinical medical students: a multi-institutional study. Acad Med 2011;86:1367-73.

121. White CB, Fantone JC. Pass-fail grading: laying the foundation for self-regulated learning. Adv Health Sci Educ Theory Pract 2010;15:469-77.

122. Spring L, Robillard D, Gehlbach L, et al. Impact of pass/fail grading on medical students' well-being and academic outcomes. Med Educ 2011;45:867-77.

123. Vosti KL, Jacobs CD. Outcome measurement in postgraduate year one of graduates from a medical school with a pass/fail grading system. Acad Med 1999;74:547-9.

124. Robins LS, Fantone JC, Oh MS, et al. The effect of pass/fail grading and weekly quizzes on first-year students' performances and satisfaction. Acad Med 1995;70:327-9.

125. Aminazadeh N, Farrokhyar F, Naeeni A, et al. Is Canadian surgical residency training stressful? Can 7 Surg 2012;55:S145-51.

126. Vogel L. Medical education needs reform to improve student well-being and reduce burnout, say experts. CMAF 2018;190:E1426-7.

127. Vogel L. Medical trainees in research-focused programs at higher risk for depression. CMA7 2019;191:E240.

128. Anderson EW, White KM. "This is what family does": The family experience of caring for serious illness. Am 7 Hosp Palliat Care 2018;35:348-54. 
129. Block J, Kremen AM. IQ and ego-resiliency: conceptual and empirical connections and separateness. F Pers Soc Psychol 1996;70:349-61.

130. Lazarus RS. From psychological stress to the emotions: a history of changing outlooks. Anпи Rev Psychol 1993;44:1-21.

131. Kumpfer KL, Bluth B. Parent/child transactional processes predictive of resilience or vulnerability to "substance abuse disorders". Subst Use Misuse 2004;39:671-98.

132. Kumpfer KL, Summerhays JF. Prevention approaches to enhance resilience among high-risk youth: comments on the papers of Dishion \& Connell and Greenberg. Ann N Y Acad Sci 2006;1094:151-63.

133. Evans TM, Bira L, Gastelum JB, et al. Evidence for a mental health crisis in graduate education. Nat Biotechnol 2018;36:282-4.

134. Storrie K, Ahern K, Tuckett A. A systematic review: students with mental health problems - a growing problem. Int 7 Nurs Pract 2010;16:1-6.

135. Skinnider MA, Squair JW, Twa DDW, et al. Characteristics and outcomes of Canadian MD/PhD program graduates: a cross-sectional survey. CMA7 Open 2017;5:E308-14

136. Brass LF, Akabas MH, Burnley LD, et al. Are MD-PhD programs meeting their goals? An analysis of career choices made by graduates of $24 \mathrm{MD}-\mathrm{PhD}$ programs. Acad Med 2010;85:692-701.

137. McKenna KM, Hashimoto DA, Maguire MS, et al. The missing link: connection is the key to resilience in medical education. Acad Med 2016;91:1197-9.

138. Kim KW, Lim HC, Park JH, et al. Developing a basic scale for workers' psychological burden from the perspective of occupational safety and health. Saf Health Work 2018;9:224-31.

139. Swanwick T, Forrest K, O'Brien BC, editors. Understanding medical education: evidence, theory, and practice. 3rd ed. Hoboken (NJ): John Wiley \& Sons, Inc.; 2019.

140. de Souza M. Promoting wholeness and wellbeing in education: exploring aspects of the spiritual dimension. In: de Souza M, Francis LJ, O'HigginsNorman J, et al., editors. International Handbook of Education for Spirituality, Care and Wellbeing. Dordrecht (The Netherlands): Springer; 2009:677-92.

141. Kripalani S, Bussey-Jones J, Katz MG, et al. A prescription for cultural competence in medical education. 7 Gen Intern Med 2006;21:1116-20.
Affiliations: Departments of Community Health Sciences (Moss, Wollny, Lorenzetti, Kassam), and Critical Care Medicine (Moss, Amarbayan), Cumming School of Medicine, and Faculty of Nursing (Wollny, Amarbayan), and School of Public Policy (Amarbayan), and Health Sciences Library (Lorenzetti), University of Calgary, Calgary, Alta.

Contributors: Stephana Moss and Aliya Kassam conceived and designed the study. All authors contributed to data acquisition, analysis and interpretation. Stephana Moss and Aliya Kassam drafted the manuscript, which all authors critically revised. All authors gave final approval of the version to be published and agreed to be accountable for all aspects of the work.

Funding: This study was funded by the Office of Postgraduate Medical Education and supported by the Office of the Senior Associate Dean of Education at the Cumming School of Medicine.

Content licence: This is an Open Access article distributed in accordance with the terms of the Creative Commons Attribution (CC BY-NC-ND 4.0) licence, which permits use, distribution and reproduction in any medium, provided that the original publication is properly cited, the use is noncommercial (i.e., research or educational use), and no modifications or adaptations are made. See: https://creativecommons.org/licenses/ by-nc-nd/4.0/

Data sharing: All data presented are available in the published record.

Supplemental information: For reviewer comments and the original submission of this manuscript, please see www.cmajopen.ca/content/9/3/ E765/suppl/DC1. 